\title{
Diversity of planktonic cyanobacteria and microcystin occurrence in Polish water bodies investigated using a polyphasic approach
}

\author{
C. Boutte ${ }^{1,2}$, J. Mankiewicz-Boczek ${ }^{3}$, J. Komarkova ${ }^{4}$, S. Grubisic ${ }^{1}$, K. Izydorczyk ${ }^{5}$, \\ F. Wautelet ${ }^{1}$, T. Jurczak ${ }^{6}$, M. Zalewski ${ }^{3}$, A. Wilmotte ${ }^{1, *}$ \\ ${ }^{1}$ Centre for Protein Engineering, Institute of Chemistry B6a, University of Liège, 4000 Liège, Belgium \\ ${ }^{2}$ Station Biologique de Roscoff, Unité Mixte de Recherche 7144, Centre National de la Recherche Scientifique, \\ BP 74, 29682 Roscoff, France \\ ${ }^{3}$ International Centre for Ecology, PAS, 3 Tylna, 90-364 Lodz, Poland \\ ${ }^{4}$ University of South Bohemia, České Budějovice, Czech Republic \\ ${ }^{5}$ Department of Applied Ecology, University of Lodz, 12/16 Banacha, 90-237 Lodz, Poland \\ ${ }^{6}$ Hydrobiological Institute, AS CR, České Budějovice, Czech Republic
}

\begin{abstract}
Microscopic measurements of fresh biomass and 16S rRNA gene sequences from clone libraries and denaturing gradient gel electrophoresis (DGGE) were used to investigate cyanobacterial diversity in Polish water bodies in 2002. In addition, measurements of microcystin (MC) concentrations were made. Thirty water samples were taken from 11 water bodies; of these samples, 18 were obtained from the Sulejow Reservoir during regular monitoring from June to October. Intraand extracellular MC concentrations in Sulejow samples were measured by high performance liquid chromatography (HPLC). The extracellular MC concentration was assessed using a protein phosphatase inhibition assay (PPIA) in additional lakes. Additionally, physicochemical parameters were measured (total nitrogen [TN], total phosphorus [TP], TN:TP ratio, chlorophyll a concentration, temperature). In Sulejow, high intracellular MC concentrations corresponded to large cyanobacterial biovolumes and to low TN:TP ratios. In the other lakes, extracellular MCs were not linked to any measured parameters. The combination of the microscopic and molecular data showed that Aphanizomenon and Microcystis were the dominant genera during the summer period in the Sulejow Reservoir. At the genetic level, there was a succession of 2 different operational taxonomic units (OTUs) belonging to the lineage Anabaena/Aphanizomenon. In the other water bodies, the most frequent populations were Aphanizomenon, Anabaena, Microcystis and Planktothrix. Small populations of Romeria, Snowella, Woronichinia, Limnothrix and Pseudanabaena were observed, and an enigmatic cluster affiliated with Prochlorothrix was genetically retrieved. Anabaena and Microcystis were presumed to be the main genera responsible for the MC production.
\end{abstract}

KEY WORDS: Genetic diversity - Cyanobacteria · Microcystins · DGGE · Population dynamics · 16S rRNA

Resale or republication not permitted without written consent of the publisher

\section{INTRODUCTION}

Cyanobacteria are among the most morphologically and physiologically diverse groups of prokaryotes. They can be found in a wide range of habitats, from ice fields to hot springs and deserts (Ward \& Castenholz
2000). The incidence and the intensity of cyanobacterial blooms have become an increasing problem at a global scale. Water temperature above $25^{\circ} \mathrm{C}$, high light intensity in the water, total nitrogen:total phosphorus (TN:TP) ratio and stability of the water column are factors responsible for the dominance of bloom-forming 
cyanobacteria (Rapala et al. 1997, Kaebernick \& Neilan 2001). Worldwide studies have shown that between 25 and $70 \%$ of the blooms are toxic (Sivonen 1996). The cyanotoxins are mainly released in the water column during collapse of the blooms. The ingestion or contact with water containing cyanobacterial cells or toxins can damage health (Pilotto et al. 1997, Carmichael et al. 2001, de Figueiredo et al. 2004). In Brazil, human deaths occurred after dialysis with water containing cyanotoxins (Pouria et al. 1998). Three main groups of cyanotoxins are usually considered on the basis of their toxicity: hepatotoxins, neurotoxins and dermatotoxins (Sivonen 1996, Chorus et al. 2000). Hepatotoxins are the most widespread toxins and include nodularins and microcystins (MCs). The latter have been extensively studied, and their production is linked to cell growth, high temperature, high light intensity and high phosphorus concentration (Rapala et al. 1997, Orr \& Jones 1998, Kaebernick \& Neilan 2001). In temperate lakes, Microcystis (Kurmayer et al. 2002), Anabaena (Beltran \& Neilan 2000) and Planktothrix (Jann-Para et al. 2004) are the main MC-producing genera responsible for the formation of blooms. Preliminary studies in Poland showed that about $78 \%$ of samples dominated by Microcystis and $84 \%$ of samples dominated by Planktothrix produced MCs (Mankiewicz-Boczek et al. 2006). Recent studies aimed to detect the genes of the MC operon mcy (Hotto et al. 2007, Saker et al. 2007). The presence of multiple MC-producing genera, identified on the basis of their mcy genes, was correlated with cyanobacterial biomass, chlorophyll a (chl a) concentration, TN and MC concentration (Rantala et al. 2006). It was proposed that specific environmental conditions may influence the presence of specific MC genotypes (Kurmayer et al. 2005).

We studied cyanobacterial diversity in relation to the occurrence of MCs using microscopic counts and molecular tools. The molecular analyses were performed using denaturing gradient gel electrophoresis (DGGE) and clone libraries based on 16S rRNA gene sequences. Thirty surface samples from 11 Polish water bodies were investigated. The Sulejow Reservoir was studied in more detail by a DGGE time-series analysis over 4 months. Cyanobacterial genera were investigated using microscopy, and biovolumes were determined for each sample. The Sulejow Reservoir is a reference water body for monitoring in Poland, and thus extracellular and intracellular MCs were measured using high performance liquid chromatography (HPLC). Additional lakes were screened using the faster protein phosphatase inhibition assay (PPIA) to obtain preliminary information about the presence of extracellular MCs. In addition, biotic and physicochemical parameters were measured and their relation to $\mathrm{MC}$ concentrations was investigated.

\section{MATERIALS AND METHODS}

Localities. The Sulejow Reservoir is a shallow, lowland reservoir, situated in central Poland in the middle course of the Pilica River. At its maximum capacity $\left(75 \times 10^{6} \mathrm{~m}^{3}\right)$, the reservoir covers $22 \mathrm{~km}^{2}$, with an average depth of $3.3 \mathrm{~m}$ and a mean retention time of approximately $30 \mathrm{~d}$. The length of the shoreline is about $54 \mathrm{~km}$, of which $34.5 \mathrm{~km}$ are forested (Ambrozewski 1980). Before April 2004, this reservoir supplied most of the drinking water for the city of Lodz (750 000 inhabitants). It is still used as an alternative source under conditions of high water demand. Moreover, it is a popular place for recreational activities such as swimming, sailing or canoeing.

Ten additional lakes were selected because they represent places of high tourist impact in 3 districts of northern Poland. Lake Jeziorak is the longest Polish lake and the largest lake in the Olsztynian Lake District. In the Mazurian District, Lakes Niegocin, Jagodne, Szymoneckie, Szymon, Kotek and Taltowisko are used for recreation and are closely connected to each other by canals. The least used water bodies are Lakes Siecino and Trzesiecko in the Pomeranian Lake District. Zegrzyn Reservoir is situated in central Poland and is a shallow and eutrophic water body. It is an important source of drinking water for Warsaw, the capital of Poland.

Sampling protocols and physicochemical analyses. Water samples were collected from the Sulejow Reservoir from 4 June to 10 October 2002 and from additional lakes from 16 August to 3 September 2002. Samples were labelled as follows: the first number represents the year (i.e. $2=2002$ ), the 2 following letters identify the lake and the last 2 digits represent the collection week. Integrated water samples from Sulejow were taken using a 51 sample from each metre of the entire water column. The other water bodies were sampled by collecting $500 \mathrm{ml}$ of surface water in bottles.

For chl a concentration and HPLC analysis, subsamples of 11 of water were immediately filtered through Whatman GF/C filters. For PPIA analysis, $1 \mathrm{ml}$ of the surface water was immediately filtered through Whatman GF/C filters. Filters were stored at $4^{\circ} \mathrm{C}$ before analysis. Two subsamples of $200 \mathrm{ml}$ were taken for chemical and molecular analysis. All samples were transported at $4^{\circ} \mathrm{C}$ to the laboratory for analysis. For molecular analysis, samples of water were filtered in the laboratory on a $0.45 \mu \mathrm{m}$ porosity Gelman Supor filter (Pall Life Science). The filter was then put into lysis buffer containing $40 \mathrm{mM}$ EDTA, $400 \mathrm{mM} \mathrm{NaCl}, 0.75 \mathrm{M}$ sucrose and $50 \mathrm{mM}$ Tris $\mathrm{HCl}$ at $\mathrm{pH} 8.3$ (Giovannoni et al. 1990) and immediately frozen.

The trophic state of studied water bodies was determined using analysis of TP and TN concentrations ac- 
cording to the Organisation for Economic Co-operation and Development (OECD) levels (limit values for eutrophication of reservoirs: $0.1 \mathrm{mg} \mathrm{P} \mathrm{l}^{-1}$ and $1.5 \mathrm{mg} \mathrm{N}^{-1}$; OECD 1982). Physicochemical parameters (TP, TN, TN:TP ratio, chl a concentration, temperature) of Sulejow were determined at the Department of Applied Ecology (University of Lodz, Poland) as described by Golterman et al. (1978). Physicochemical parameters of additional lakes were determined according to Janczak (1999) and the Inspectorate for Environmental Protection.

MC determination. High performance liquid chromatography (HPLC): Intracellular (cyanotoxins in cells) and extracellular (cyanotoxins dissolved in water) forms of MCs were measured. For intracellular toxins, the samples were sonicated for $30 \mathrm{~s}$ in a Misonix ultrasonicator and liquid processor XL. The extracts were centrifuged twice at $11000 \times g$ for $10 \mathrm{~min}$ at $4^{\circ} \mathrm{C}$. The supernatants were collected and evaporated in an SC110A Speedvacs Plus ThermoSavant. Samples were re-dissolved in $1 \mathrm{ml}$ of $75 \%$ aqueous methanol and filtered through a Gelman GHP Acrodisc $13 \mathrm{~mm}$ syringe filter with $0.45 \mathrm{~mm}$ GHP membrane and minispike outlet. For dissolved MCs, 1 l of filtered water sample was concentrated before HPLC analysis by solid phase extraction (SPE) and eluted from C18 cartridges by $90 \%$ aqueous methanol with $0.1 \%$ trifluoroacetic acid (TFA). Methanol was evaporated and samples were redissolved in $1 \mathrm{ml}$ of $75 \%$ aqueous methanol before HPLC analysis (Jurczak et al. 2005).

The samples were analysed using an Agilent 1100 series composed of a quaternary pump, autosampler and thermostated column compartment. Chromatographic separation was achieved using a Merck Purospher Star RP-18e column $(55 \times 4 \mathrm{~mm} ; 3 \mu \mathrm{m})$ with a $\mathrm{C}_{18}$ guard column $(4 \times 4 \mathrm{~mm})$. The determination of $\mathrm{MCs}$ by HPLC-diode array detector (DAD) was performed using a gradient mobile phase of $\mathrm{H}_{2} \mathrm{O}+0.05 \%$ TFA (eluent A), acetonitrile (ACN) $+0.05 \%$ TFA (eluent B) and diode-array detection at 200 to $300 \mathrm{~nm}$. The linear gradient conditions were as follows: $25 \% \mathrm{~B}$ at $0 \mathrm{~min}$, $70 \% \mathrm{~B}$ at $5 \mathrm{~min}, 70 \% \mathrm{~B}$ at $6 \mathrm{~min}, 25 \% \mathrm{~B}$ at $6.10 \mathrm{~min}$. Injection volume was $20 \mu \mathrm{l}$, flow rate was $1 \mathrm{ml} \mathrm{\textrm {min } ^ { - 1 }}$ and column temperature was $40^{\circ} \mathrm{C}$. MCs in the cyanobacterial extracts were identified against the standards for MC-LR, MC-RR, demethylated-MC-RR, MC-YR, MC-LY, MC-LW, MC-LF by their characteristic absorption spectra and retention times (Jurczak et al. 2005, Meriluoto \& Codd 2005). This method enables detection of MCs at the $0.01 \mu \mathrm{g}^{-1}$ level after concentration of the sample.

Protein phosphatase inhibition assay (PPIA): A colorimetric PPIA with the enzyme protein phosphatase 1 (PP1) was used to determine the extracellular MC concentrations. The inhibition by MCs of PP1 from rabbit skeletal muscle (New England BioLabs) was estimated according to An \& Carmichael (1994) with minor modifications (Meriluoto \& Codd 2005). Hydrolysis of p-nitrophenyl phosphate (pNPP), which is the indicator of PP1 activity, was measured by the formation of $\mathrm{p}$ nitrophenol (pNP). The pNPP (15 mM) was dissolved in buffer containing $50 \mathrm{mM}$ Tris- $\mathrm{HCl}$ (8.1), $20 \mathrm{mM} \mathrm{MgCl}_{2}$, $0.2 \mathrm{mM} \mathrm{MnCl}_{2}, 2 \mathrm{mM}$ DTT and $0.5 \mathrm{mg} \mathrm{ml}^{-1} \mathrm{BSA}$. The PP1 was diluted to $1.7 \mathrm{U} \mathrm{ml}^{-1}$ in the buffer containing $50 \mathrm{mM}$ Tris- $\mathrm{HCl}$ (7.4), $1 \mathrm{mM} \mathrm{MnCl}_{2}, 2 \mathrm{mM}$ DTT and $1 \mathrm{mg} \mathrm{ml}^{-1} \mathrm{BSA}$. Different concentrations of MC-LR in Milli-Q water (MC-LR) were used as standards (Calbiochem). The assay was prepared by adding $200 \mu \mathrm{l}$ substrate (pNPP), $10 \mu \mathrm{l}$ negative control (Milli-Q water), $10 \mu$ l enzyme (PP1) and $10 \mu$ standard solution of MC-LR or filtrated water sample containing dissolved MC (PP1). The pNP production was measured after $2 \mathrm{~h}$ incubation at $37^{\circ} \mathrm{C}$ by analysing absorbance in the $405 \mathrm{~nm}$ range using a microplate analyser (Labsystems). This method enables the detection of MCs at a threshold of $0.125 \mu \mathrm{g} \mathrm{l}^{-1}$, without concentration of the sample.

Microscopic analysis: Fresh samples of phytoplankton were investigated for species composition and the populations were registered using photography on an Olympus BX51 microscope equipped with an Olympus DP70 digital camera. The assessment of the phytoplankton biomass was done by counting the cells settled in Utermöhl chambers (Lund 1951) using an Olympus IMT2 inverted microscope. To estimate the biovolume of the algae and cyanobacteria, 30 to 100 individual cells were measured and their volumes calculated according to geometrical solids. Filaments with invisible cells (Planktolyngbya) were measured and their biomass was calculated as for cylinders. Results were expressed as fresh biomass in $\mu \mathrm{g} \mathrm{l}^{-1}$ (Javornický \& Komárková 1973) assuming the specific density of phytoplankton as a unit $\left(10^{6} \mu \mathrm{m}^{3}=1 \mu \mathrm{g}\right)$. At least 400 cells or settling units (colonies, filaments) were counted to reduce the error to less than $10 \%(p=0.05$, Javornický 1958). A computing program developed at the Hydrobiological Institute for internal use (Phyto-N) was used to calculate the biovolume from the cell numbers.

Molecular analysis. DNA extraction and 16S rRNA PCR-DGGE: DGGE analyses targeting $480 \mathrm{pb}$ of the V3 and V4 regions of 16S rRNA were performed as described by Boutte et al. (2006), with the following modifications for the first PCR reaction. It included 1 cycle of initial denaturation at $94^{\circ} \mathrm{C}$ for $5 \mathrm{~min}, 30$ (if the semi-nested PCR was made with CYA781RGC[a]) or 20 cycles (if the semi-nested PCR was made with CYA781RGC[b]) of $45 \mathrm{~s}$ at $94^{\circ} \mathrm{C}, 45 \mathrm{~s}$ at $54^{\circ} \mathrm{C}$ and $2 \mathrm{~min}$ at $68^{\circ} \mathrm{C}$. Two DGGE fingerprints were obtained for each sample, called (a) for the CYA359F-CYA781- 
RGC(a) amplification and (b) for CYA359F-CYA781RGC(b) amplification. The labels of the DGGE sequences correspond to the name of the sample, followed by the type of amplification, i.e. 'dggea' for (a) or 'dggeb' for (b). The central parts of all visible bands were extracted, re-amplified and sequenced with no further purification step. When the same pattern of bands was obtained from multiple samples, only the bands of 1 representative sample were chosen for sequencing. A standard marker composed of CYA359F-CYA781RGC(a) amplifications of DNA from strains Cylindrospermum PCC7417, Calothrix 328, Aphanizomenon 202a and Nostoc 152 and of CYA359F-CYA781RGC(b) amplifications of DNA from Microcystis 130 and Synechococcus GL150636 were added in each gel.

DGGE dendrogram: Two DGGE fingerprints (a) and (b) were obtained from each sample and analysed using GelCompar II Software 2.5 (Applied Maths). The bands were localised on the basis of densitometric curves. The lanes were aligned using the standard marker. Cluster analyses were performed separately for Sulejow and the other lakes using the combination of the DGGE patterns produced with primer pairs (a) and (b). Clustering was performed using the position of the bands and the normalised intensity value. A Dice index similarity matrix was calculated using the peaks showing more than $5 \%$ of the maximum peak intensity and area. The dendrogram was built with the Ward method as implemented in the software.

Cloning: The samples corresponding to Sulejow $02 / 10 / 02$ (2SU40; dates are presented in the form $\mathrm{dd} / \mathrm{mm} / \mathrm{yy}$ ) and Szymoneckie 16/08/02 (2SY33) were analysed using a clone library. For the 2 clone libraries, PCR amplifications targeting the 16S rRNA and ITS were carried out with the forward primer CYA359F (Nübel et al. 1997) and 23S30R (Taton et al. 2003). The PCR conditions included an initial denaturation step of 5 min at $94^{\circ} \mathrm{C}$, followed by 30 cycles, each consisting of $45 \mathrm{~s}$ at $94^{\circ} \mathrm{C}, 45 \mathrm{~s}$ at $54^{\circ} \mathrm{C}$ and 2 min at $68^{\circ} \mathrm{C}$. A last incubation of 7 min at $68^{\circ} \mathrm{C}$ was performed. The PCR products were purified with the Quantum Prep PCR Kleen spin columns (Biorad). dATP was added to the 3 'end with the A-addition kit (Qiagen). The cloning kit $\mathrm{pCR}^{\circledR} 2.1$ - $\mathrm{TOPO}^{\circledR}$ (Invitrogen) was used following the manufacturer's instructions. PCR amplicons of approximately $2 \mathrm{~kb}$ were ligated into the plasmid vector $\mathrm{pCR}^{\circledR} 2.1$ and transformed into TOP10 chemically competent Escherichia coli. The colonies were screened by direct PCR with primers CYA359F and CYA784R using an annealing temperature of $60^{\circ} \mathrm{C}$ instead of $54^{\circ} \mathrm{C}$ to increase the specificity of the detection. Each positive clone was sequenced with primer 1092R (Hrouzek et al. 2005). Sequencing reactions were carried out using an ABI Prism system 377 (PE Applied Biosystems) by the company Genome Express (France). Sequences were manually corrected and chimeras were identified with CheckChimera (Cole et al. 2003) and removed.

Prochlorothrix hollandica and pcbC gene detection: To detect the presence of Prochlorothrix hollandica, the DNA extracted from each environmental sample was submitted to a PCR amplification using the 16S-Pholl-fw/16S-Pholl-rev primer pair that specifically targets the $16 \mathrm{~S}$ rRNA gene of $P$. hollandica (Geiss et al. 2003). In addition, PCR detection of the gene $p c b \mathrm{C}$ of the operon encoding the $\mathrm{chl} a / b$ binding protein was carried out using primers $p c b \mathrm{C}$-fw and $p c b \mathrm{C}$ rev as described by Geiss et al. (2003) to detect chl $b$ containing oxyphotobacteria.

BLAST analysis, phylogenetic reconstruction and Operational taxonomic unit (OTU) determination: For each sequence, the 2 most similar sequences found by a BLAST analysis were chosen as reference sequences. The positions 368 to 751 (based on the Escherichia coli sequence) of the partial 16S rRNA sequences from DGGE, clone and reference sequences were aligned using CLUSTALW (Thompson et al. 1994). A distance matrix was calculated using the Jukes and Cantor correction for multiple mutations, and insertion/deletions were not taken into account. The distance tree was constructed with the neighbor-joining (NJ) method with the software TREECON (Van de Peer \& De Wachter 1994). We used 383 positions (368 to 751, E. coli numbering). The E. coli sequence was used as the outgroup. A bootstrap analysis involving 500 replicates was performed. Sequences sharing more than $97.5 \%$ similarity (Stackebrandt \& Goebel 1994, Taton et al. 2003) were grouped into OTUs using the software DOTUR (Schloss \& Handelsman 2005) with the 'Furthest Neighbor' algorithm. An accumulation curve was constructed using Species Diversity and Richness version 2.62 (Pisces Conservation) to assess the completeness of the clone libraries (Hughes et al. 2001).

To avoid submitting almost identical sequences, the DGGE sequences sharing more than $99 \%$ similarity were grouped as described above. One representative DGGE sequence per lake and per group was deposited in GenBank under accession numbers DQ531850 to DQ531878. An identical strategy was followed for the clone libraries, and the representative clone sequences were recorded under accession numbers DQ531879 to DQ531933.

Statistical analysis. Because of the low number of samples, the non-parametric and non-linear Spearman's rank coefficient $\left(\mathrm{r}_{\mathrm{s}}\right)$ was used to investigate correlation between parameters. For each sample, the biovolume of each cyanobacterial genus, the total biovolume, the biotic (TP, TN, TN:TP ratio, chl a concentration, total MC concentration, extracellular and intracellular $\mathrm{MC}$ concentration) and abiotic factors (temperature) were used to calculate Spearman's rank correlation. 


\section{RESULTS}

\section{Physicochemical parameters of the water bodies}

The Sulejow Reservoir is a eutrophic ecosystem. Average TP concentrations of 0.06 to $0.2 \mathrm{mg} \mathrm{l}^{-1}$ and TN of 0.6 to $3.6 \mathrm{mg} \mathrm{l}^{-1}$ were measured throughout the summer-autumn in 2002 (Table 1). Lake Jeziorak showed an average TP concentration of $0.13 \mathrm{mg} \mathrm{l}^{-1}$ and an average TN of $1.9 \mathrm{mg} \mathrm{l}^{-1}$ throughout the summer season. All lakes of the Mazurian were eutrophic: an average TP concentration of 0.2 to $0.3 \mathrm{mg} \mathrm{l}^{-1}$ and an average TN of 1.6 to $1.9 \mathrm{mg} \mathrm{l}^{-1}$ were detected throughout the summer season. TP concentrations of $0.2 \mathrm{mg} \mathrm{l}^{-1}$ and TN of $1.9 \mathrm{mg} \mathrm{l}^{-1}$ were obtained for the Zegrzyn Reservoir. In Lakes Siecino and Trzesiecko, the average TP concentration was $0.1 \mathrm{mg} \mathrm{l}^{-1}$ and the average TN was $1.0 \mathrm{mg} \mathrm{l}^{-1}$ for the former and $0.1 \mathrm{mg} \mathrm{l}^{-1}$ and $2.6 \mathrm{mg} \mathrm{l}^{-1}$ for the latter.

\section{MCs and chl a concentrations in selected Polish water bodies}

MC-RR, -YR and -LR were the most common variants of MCs in Poland (Jurczak et al. 2004). In Sulejow Reservoir, the extracellular MC concentration was quite low $\left(<0.3 \mathrm{\mu g} \mathrm{l}^{-1}\right)$ and intracellular MCs contributed $90 \%$ of the total MCs on average. The highest hepatotoxin concentration $\left(6.7 \mu \mathrm{g}^{-1}\right)$ was obtained at the beginning of August when the chl a concentration was $44.6 \mathrm{Mg} \mathrm{l}^{-1}$. In September, the total concentration of MCs was in the range of 1.1 to $2.3 \mu \mathrm{g} \mathrm{l}^{-1}$, and the chl a concentrations varied from 12.4 to $15.5 \mu \mathrm{g} \mathrm{l}^{-1}$.

In the additional lakes, PPIA also indicated the presence of extracellular MCs at the surface (Table 1). The highest MC concentration (ca. $5 \mu \mathrm{g} \mathrm{l}^{-1}$ ) was found in the Pomeranian lakes Trzesiecko and Siecino. MCs in Lakes Jeziorak and Szymoneckie reached 4.2 and $4.3 \mu \mathrm{g} \mathrm{l}^{-1}$, respectively. The range of MC concentra-

Table 1. Field samples collected from Polish water bodies in summer 2002. Dates given as dd/mm/yy; MC: microcystins; nd: not determined

\begin{tabular}{|c|c|c|c|c|c|c|c|c|c|}
\hline $\begin{array}{l}\text { Water } \\
\text { body }\end{array}$ & Code & $\begin{array}{l}\text { Air } \\
\text { temp. } \\
\left({ }^{\circ} \mathrm{C}\right)\end{array}$ & $\begin{array}{c}\text { Date of } \\
\text { collection }\end{array}$ & $\begin{array}{c}\text { Total P } \\
\left(\mathrm{TP} ; \mathrm{mg} \mathrm{l}^{-1}\right)\end{array}$ & $\begin{array}{c}\text { Total N } \\
\left(\mathrm{TN}_{;} \mathrm{mg} \mathrm{l}^{-1}\right)\end{array}$ & $\begin{array}{l}\mathrm{TN}: \mathrm{TP} \\
\text { ratio }\end{array}$ & $\begin{array}{c}\text { Chl a } \\
\left(\mu g \mathrm{l}^{-1}\right)\end{array}$ & $\begin{array}{c}\text { Intracellular } \\
\mathrm{MC} \\
\left(\mu \mathrm{g} \mathrm{l}^{-1}\right)\end{array}$ & $\begin{array}{c}\text { Extracellular } \\
\mathrm{MC} \\
\left(\mu \mathrm{g} \mathrm{l}^{-1}\right)\end{array}$ \\
\hline \multirow[t]{18}{*}{ Sulejow } & 2SU23 & 21.4 & 04/06/02 & 0.11 & 2.10 & 19.1 & nd & nd & nd \\
\hline & 2SU24 & 17.8 & $12 / 06 / 02$ & 0.07 & 2.20 & 31.4 & nd & nd & nd \\
\hline & 2SU25 & 19.1 & 18/06/02 & 0.13 & 3.60 & 27.7 & nd & nd & nd \\
\hline & 2SU26 & 22.4 & 26/06/02 & 0.06 & 2.90 & 48.3 & 1.10 & nd & nd \\
\hline & 2SU28 & 22.6 & 08/07/02 & 0.10 & 2.10 & 21.0 & 1.90 & nd & nd \\
\hline & 2SU29 & 24.5 & $17 / 07 / 02$ & 0.08 & 2.30 & 28.8 & 2.30 & nd & nd \\
\hline & 2SU30 & 22.6 & $24 / 07 / 02$ & 0.08 & 2.10 & 26.3 & 2.30 & $0.90^{\mathrm{a}}$ & $0.21^{\mathrm{b}}$ \\
\hline & 2SU31 & 26.4 & 01/08/02 & 0.11 & 3.10 & 28.2 & 3.90 & $0.52^{\mathrm{a}}$ & $0.00^{\mathrm{b}}$ \\
\hline & 2SU32 & 22.8 & 07/08/02 & 0.12 & 2.10 & 17.5 & 44.6 & $6.55^{\mathrm{a}}$ & $0.13^{\mathrm{b}}$ \\
\hline & 2SU33 & 22.2 & $13 / 08 / 02$ & 0.17 & 1.70 & 10.0 & 5.90 & $2.21^{\mathrm{a}}$ & $0.25^{\mathrm{b}}$ \\
\hline & 2SU34 & 23.7 & $22 / 08 / 02$ & 0.13 & 1.30 & 10.0 & 35.90 & $3.13^{\mathrm{a}}$ & $0.27^{b}$ \\
\hline & 2SU35 & 22.3 & 28/08/02 & 0.10 & 2.40 & 24.0 & 13.50 & $1.23^{\mathrm{a}}$ & $0.11^{b}$ \\
\hline & 2SU36 & 22.1 & 04/09/02 & 0.09 & 0.60 & 6.7 & 12.40 & $2.08^{a}$ & $0.21^{\mathrm{b}}$ \\
\hline & 2SU37 & 20.6 & $11 / 09 / 02$ & 0.20 & 2.90 & 14.5 & 13.70 & $1.03^{\mathrm{a}}$ & $0.10^{\mathrm{b}}$ \\
\hline & 2SU38 & 17.0 & 19/09/02 & 0.18 & 2.10 & 11.7 & 15.50 & $1.69^{\mathrm{a}}$ & $0.06^{\mathrm{b}}$ \\
\hline & 2SU39 & 14.2 & $25 / 09 / 02$ & 0.14 & 1.40 & 10.0 & 12.40 & $1.69^{\mathrm{a}}$ & $0.19^{b}$ \\
\hline & 2SU40 & 14.0 & $02 / 10 / 02$ & 0.13 & 1.80 & 13.8 & 4.80 & $0.61^{\mathrm{a}}$ & $0.15^{\mathrm{b}}$ \\
\hline & 2SU41 & nd & $10 / 10 / 02$ & nd & nd & nd & 5.20 & $1.03^{\mathrm{a}}$ & $0.21^{\mathrm{b}}$ \\
\hline \multirow[t]{3}{*}{ Jeziorak } & 2JE31 & nd & 04/08/02 & nd & nd & nd & nd & nd & nd \\
\hline & 2JE35 & nd & $26 / 08 / 02$ & nd & nd & nd & nd & nd & nd \\
\hline & 2JE36 & nd & 03/09/02 & $0.13^{d}$ & $1.9^{\mathrm{d}}$ & 14.6 & $55.6^{\mathrm{d}}$ & nd & $4.15^{\mathrm{c}}$ \\
\hline Niegocin & 2NI33 & nd & 16/08/02 & $0.32^{\mathrm{d}}$ & $1.6^{\mathrm{d}}$ & 5.0 & $19.7^{\mathrm{d}}$ & nd & $2.22^{\mathrm{c}}$ \\
\hline Jagodne & 2JA33 & nd & $16 / 08 / 02$ & $0.19^{\mathrm{d}}$ & $1.9^{\mathrm{d}}$ & 10.0 & $26.7^{\mathrm{d}}$ & nd & $2.72^{\mathrm{c}}$ \\
\hline Szymoneckie & 2SY33 & nd & $16 / 08 / 02$ & $0.19^{\mathrm{d}}$ & $1.9^{\mathrm{d}}$ & 10.0 & $26.7^{\mathrm{d}}$ & nd & $4.25^{\mathrm{c}}$ \\
\hline Szymon & 2SZ33 & nd & $16 / 08 / 02$ & $0.20^{\mathrm{d}}$ & $1.6^{\mathrm{d}}$ & 8.0 & $30.8^{\mathrm{d}}$ & nd & $1.82^{\mathrm{c}}$ \\
\hline Kotek & 2KO33 & nd & 16/08/02 & nd & nd & nd & nd & nd & $2.08^{\mathrm{c}}$ \\
\hline Taltowisko & 2TL33 & nd & $16 / 08 / 02$ & $0.34^{\mathrm{d}}$ & $1.9^{\mathrm{d}}$ & 5.6 & $15.3^{\mathrm{d}}$ & nd & $2.97^{\mathrm{c}}$ \\
\hline Zegrzyn & 2ZE34 & nd & $22 / 08 / 02$ & $0.18^{\mathrm{d}}$ & $1.9^{\mathrm{d}}$ & 10.6 & $14.2^{\mathrm{d}}$ & nd & $0.67^{\mathrm{c}}$ \\
\hline Siecino & 2SI35 & nd & $27 / 08 / 02$ & $0.07^{d}$ & $1.0^{\mathrm{d}}$ & 13.9 & $7.2^{\mathrm{d}}$ & nd & $4.97^{\mathrm{c}}$ \\
\hline Trzesiecko & 2TR35 & nd & $27 / 08 / 02$ & $0.11^{\mathrm{d}}$ & $2.6^{\mathrm{d}}$ & 23.6 & nd & nd & $5.31^{\mathrm{c}}$ \\
\hline \multicolumn{10}{|c|}{ antracellular concentration of microcystins determined by HPLC } \\
\hline \multicolumn{10}{|c|}{ bxtracellular concentration of microcystins determined by HPLC } \\
\hline \multicolumn{10}{|c|}{${ }^{\mathrm{c} E x t r a c e l l u l a r}$ concentration of microcystins in water determined by PPIA } \\
\hline${ }^{\mathrm{d}}$ Average su & r & & & & & & & & \\
\hline
\end{tabular}


tions in the other Mazurian lakes ranged from 1.8 to $3 \mu \mathrm{g} \mathrm{l}^{-1}$. The lowest MC concentration $\left(0.7 \mu \mathrm{g}^{-1}\right)$ was observed in the Zegrzyn Reservoir.

\section{Microscopic counts}

The biovolume calculations showed that in June (2SU23 to 2SU26), the Sulejow samples were dominated by Anabaena, Microcystis and some picoplankton (Fig. 1A). Aphanizomenon and Microcystis were the major populations in the samples from July to October (2SU28 to 2SU41). In the additional lakes, the largest biovolumes corresponded to Pseudanabaena for the 2 Jeziorak samples observed (Fig. 1B). Microcystis, Aphanizomenon, Anabaena, Planktothrix and Microcystis were dominant for the other samples. In addition, some minor populations of Planktolyngbya (2JE31, 2JE36, 2SY33, 2TL33, 2SI35), Synechococcus (2JE36, 2SI35, 2TR35) and Romeria (2TR35) were also observed. Microscopic data for 2JE35 are missing.

\section{Molecular analysis of cyanobacterial diversity in Polish water bodies}

Phylogenetic reconstruction and OTU determination. On the basis of the DGGE and clone sequences, 12 OTUs were found among 7 genera (Fig. 2). Anabaena/Aphanizomenon contained 4 OTUs (1, 2, 3 and 4). The cluster Limnothrix/Pseudanabaena included 3 OTUs $(10,11$ and 12). These 2 clusters showed the lowest internal sequence similarity (91.1 and 97.1\%, respectively). Each of the other clusters corresponded to only 1 OTU: Planktothrix (OTU 5), Synechococcus (OTU 6), Snowella (OTU 7), Microcystis (OTU 8) and the Prochlorothrix-like cluster (OTU 9). They had an average internal similarity of $99.3 \%$.

DGGE profile of Sulejow Reservoir. For the Sulejow Reservoir, 32 bands were sequenced: 23 from the (a) patterns and 9 from the (b) patterns. On the basis of the dendrograms obtained, different phases were distinguished (Fig. 3A). A first phase was observed in June (2SU23 to 2SU25) with very weak bands (Group 1). The bands successfully sequenced from these patterns belonged to OTU 2 of the cluster Anabaena/Aphanizomenon for (a) (2SU23-dggea1,a2) and to Microcystis (OTU 8, 2SU24-dggeb1) for (b) (see Fig. 2).

A second phase was observed in July and August (2SU26 to 2SU36), with quite variable DGGE patterns (Group 2). The sequences retrieved from these samples were included in the Anabaena/Aphanizomenon cluster (12 sequences from samples 2SU30 and 2SU32 in OTUs 1 and 2), in the Microcystis cluster (OTU 8, 2SU29-dggea1,b1, 2SU26-dggeb1 and b2) and in the Limnothrix/Pseudanabaena cluster (OTU 12, 2SU26dggea6) (Fig. 2). However, the pattern of the sample 2SU30 was slightly different from the others and had a high number of bands affiliated to Anabaena/Aphanizomenon (OTU 2).

The third phase corresponded to September and November (2SU37 to 2SU41, Group 3). All bands sequenced from these patterns belonged to Anabaena/Aphanizomenon cluster (OTU 1) or Microcystis (OTU 8), except for 1 band in the Limnothrix/Pseudanabaena cluster (OTU 10, 2SU37-dggea1). Pattern (b) corresponding to 2SU35 was also different from the others. The 2 bands situated in the middle part of the gel were related to the Prochlorothrix-like cluster (OTU 9, 2SU35-dggeb3, b4).

DGGE profiles of additional lakes. For the 12 samples taken in the 10 additional lakes, 22 sequences were produced from the excised bands (10 for pattern [a] and 12 for pattern [b]; see Fig. 3B).

The sequences of the bands retrieved from pattern (a) were generally related to the OTUs 2, 3 and 4 of the Anabaena/Aphanizomenon cluster (Fig. 2). Most sequences recovered from pattern (b) were related to Microcystis. However, a different diversity was found in samples 2NI33, 2SI35, 2TR35 and 2ZE34 (Group 1). In sample 2TR35, 1 band was related to the Microcystis cluster (OTU 8, 2TR35-dggea2) and 1 band belonged to the Limnothrix/Pseudanabaena cluster (OTU 10, 2TR35-dggea1). One band in 2SI35 (2SI35-dggeb3, OTU 6) exhibited a similarity of $100 \%$ with Synechococcus PS723 (isolated from Lake Biwa, Japan; Robertson et al. 2001), and another sequence from 2SI35 was affiliated to the Snowella cluster (OTU 7).

The 3 fingerprints from Lake Jeziorak (2JE31, -35, -36) showed nearly identical patterns (Group 2, ca. $85 \%$ similarity). Except for 2NI33, the patterns of the lake samples taken in the Mazurian District clustered together (2KO33, 2JA33, 2TL33, 2SZ33, 2SY33, Group 3). Samples 2JA33 and 2SY33 showed very poor diversity for the (a) and (b) amplifications. Samples 2TL33 and 2JE31 had sequences belonging to the Prochlorothrix-like cluster (OTU 9).

Clone libraries. For the clone library of Sulejow (02/10/02, 2SU40), 79 sequences were obtained, of which $72 \%$ corresponded to OTU 1 in the Anabaenal Aphanizomenon cluster (57 sequences), 20 sequences were positioned in the cluster of Microcystis (OTU 8) and 2 sequences were in the Limnothrix/Pseudanabaena cluster (OTU 10) (Fig. 2).

Fig. 1. Relative shares of individual genera calculated on the basis of their biovolumes for samples from (A) Sulejow Reservoir and (B) other lakes. For each sample, the total biovolume in $\mu \mathrm{g} \mathrm{ml}^{-1}$ is indicated; dates are given as dd/mm/yy 

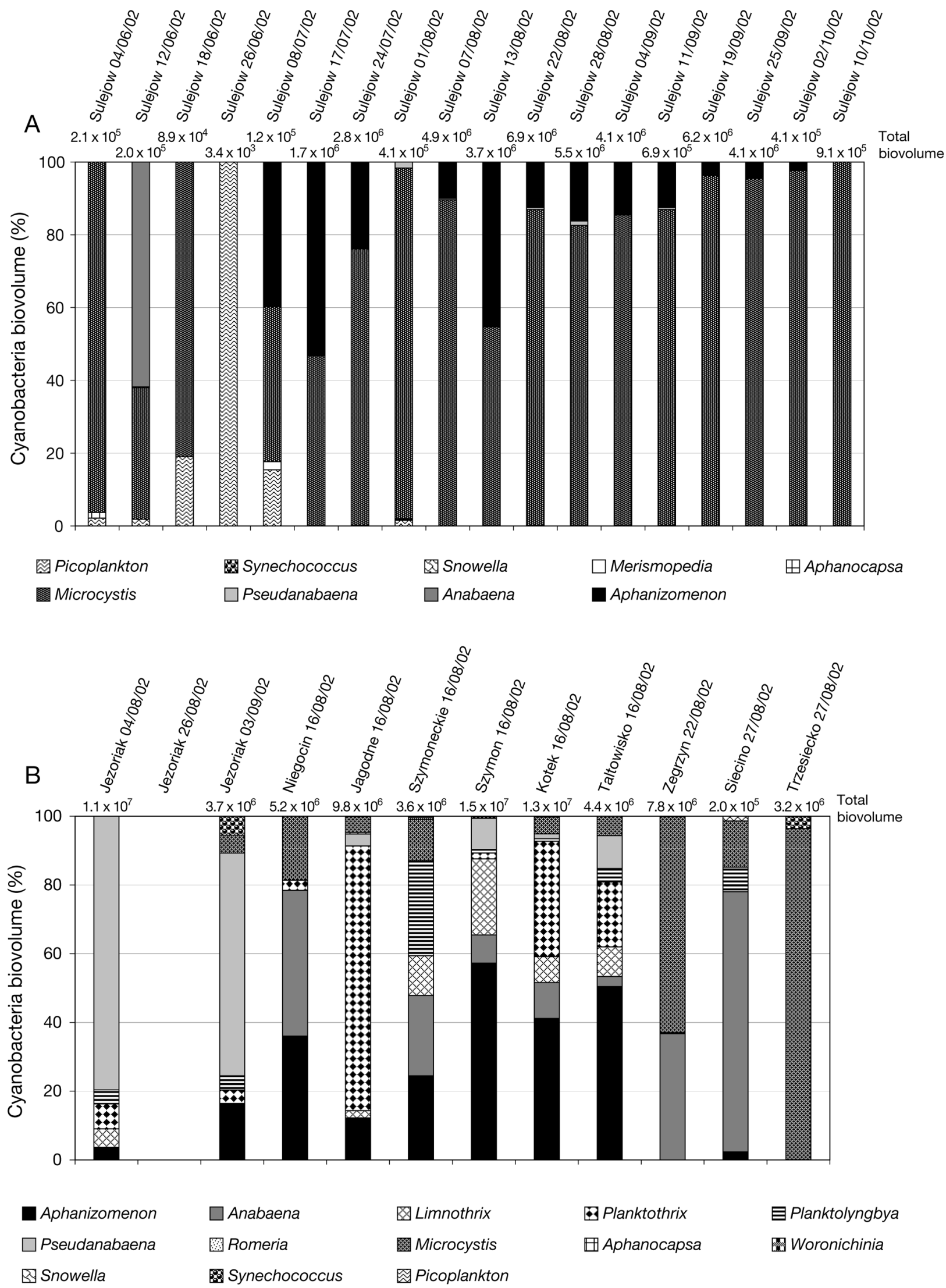
Fig. 2. Distance tree of the 54 DGGE sequences, 106 clone sequences, 3 published reference sequences of clones and 29 published reference sequences of strains (italics). Bootstrap values $>80 \%$ are given beside the nodes. The scale indicates the evolutionary distance. Identical sequences obtained from the same sample by DGGE or cloning are represented by 1 sequence. Names of the duplicate DGGE sequences and the number of the identical clone sequences are given in parentheses beside the representative sequence. For each cluster, the minimum internal similarity is given. Each OTU is indicated by dashed lines
Distance 0.1

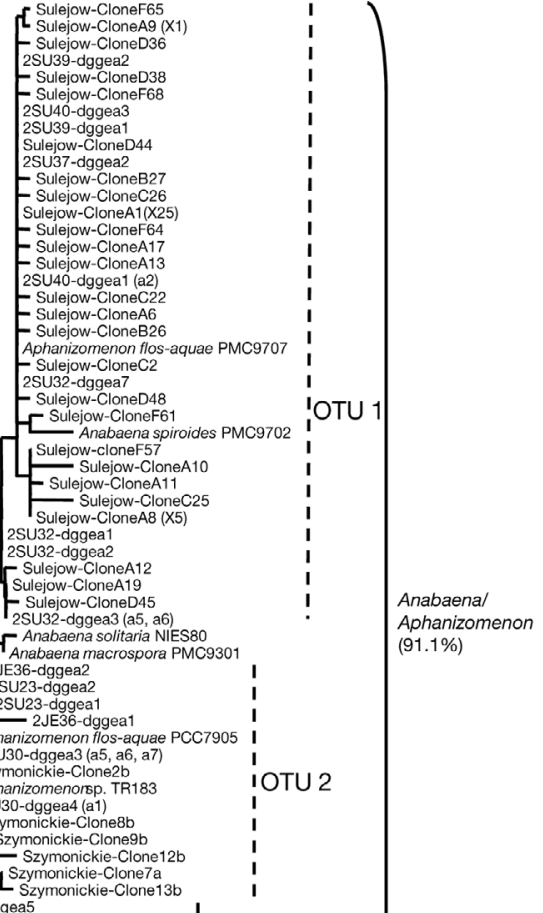
KO33-dggea5
2KO33-dggea 4

Anabaenacf. cylindrica PMC9705 I

Anabaenacf.cylindrica PMC 9705 ,

Szymonickie-Clone14b

Szymonickie-Clone4a (X1) IOTU 3

- Szymonickie-Clone12A

4 Szymonickie-clonega $(x)$ Szymonicki-Clone $15 \mathrm{~b}$ $974^{2 N 133-d g g e a 5}(a 4, a 7)$

$$
\text { OTU } 3
$$

$$
\text { I }
$$$$
\text { ?. }
$$

strain

च':OTU 4

100 Szymonickie-Clone5b

I

Oscillatoria sp. strain 2
Oscillatoria sp. CYA128 R

Oscillatoria agardhii taxon 1160 IOTU 5 Planktothrix (98.9\%)

- Szymonickie-Clone1

94 Szymonickie-Clone3a

Szymonickle-Clone2a

Synechococcus sp. TAG I

2Sl35-dggeb3

122 I'OTU 7] IOTU 6 Synechococcus (100\%)

Woronichinia naegeliana 1ES42-S1
$1001^{2 T R 35-d g g e a ?}$

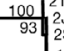

2JA33-dggeb1
2SU24-dggeb1

$\bigsqcup_{2 \mathrm{SU}}^{2 \mathrm{~N} 130 \text {-dggeb1 (b2) }}$

- 2SU40-dggeb3

2SU26-dggeb2

L 1 2SU29-dggea1

2SU29-dggeb1
Sulejow-CloneD35

Microcystis aeruginosa UWOCC C1 Microcystis aeruginosa UWOCC C1
Microcystis viridis NIVA-CYA 169/7

Sulejow-CloneC13 (X1)

4 Sulejow-CloneF52

4 Sulejow-CloneA7 (X7) Sulejow-CloneA7 (X7)
Microcystis flos-aquae UWOCC C3
Microcystiscf. wesenbergii NIVA-CYA 172/1 Vicrocystis aeruginosa KCTC AG10159 Sulejow-CloneC29
- Sulejow-CloneC9 (X1) Sulejow-CloneD34 (X1) 2KO33-dggeb3

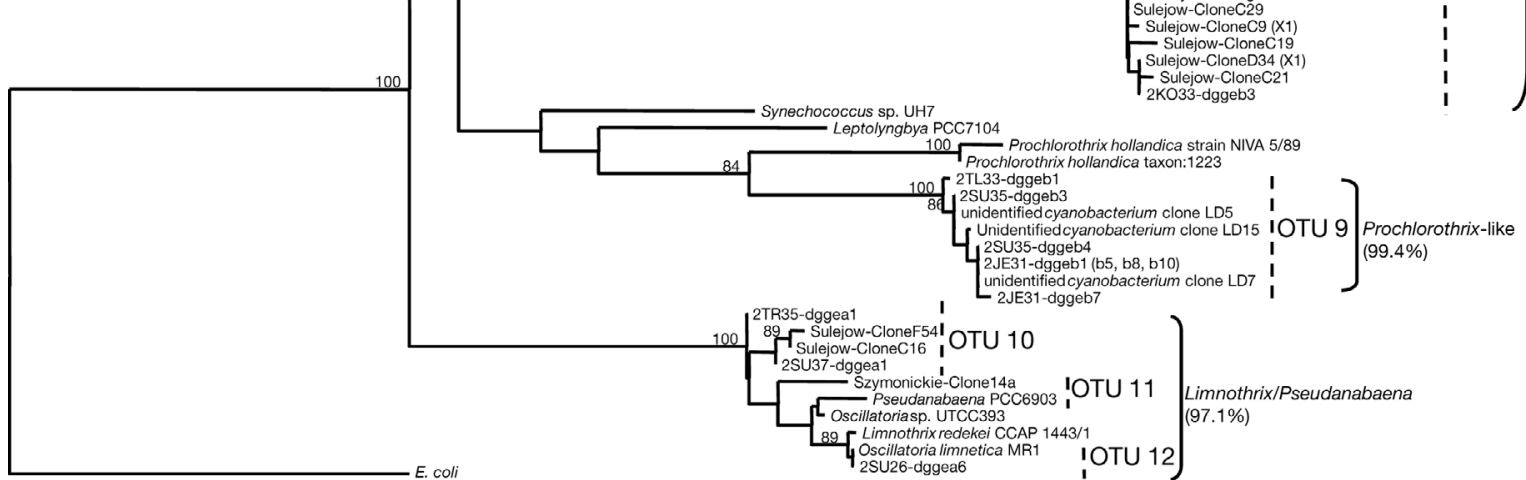



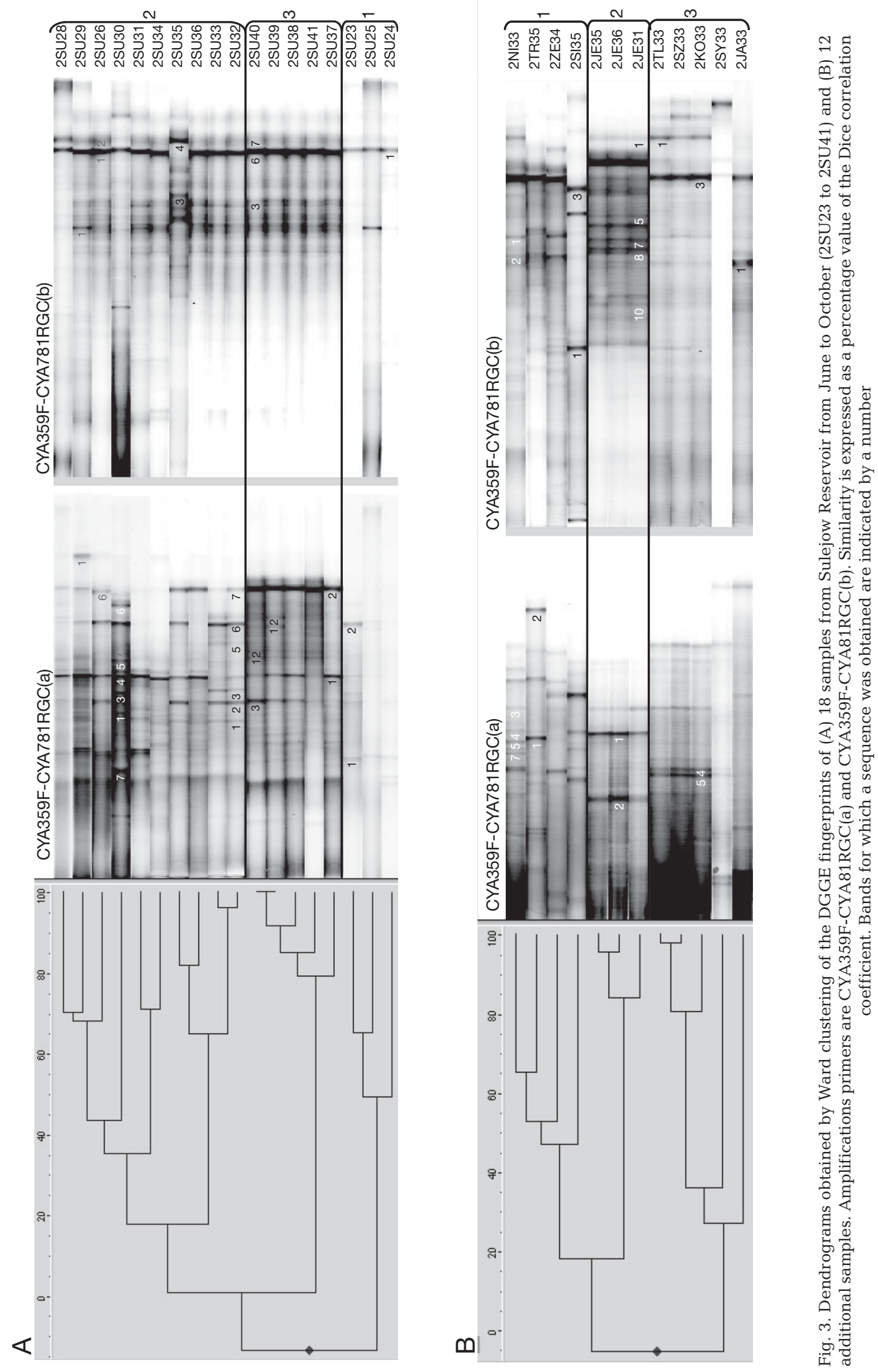
Table 2. Spearman's rank correlation coefficients between biotic and abiotic parameters. Correlations obtained for intracellular and extracellular microcystins are indicated in brackets. Genera showing correlations lower than 0.60 are not shown. Correlations higher than 0.65 are in bold

\begin{tabular}{|c|c|c|c|c|c|c|}
\hline \multirow{2}{*}{ No. } & \multirow{2}{*}{ Parameter (unit) } & & & \multirow{2}{*}{$\begin{array}{c}\text { Correlation } \\
3\end{array}$} & \multirow[b]{2}{*}{4} & \multirow[b]{2}{*}{5} \\
\hline & & 1 & 2 & & & \\
\hline 1 & Temperature $\left({ }^{\circ} \mathrm{C}\right)$ & 1.00 & & & & \\
\hline 2 & $\mathrm{TN}\left(\mathrm{mg} \mathrm{l}^{-1}\right)$ & -0.43 & 1.00 & & & \\
\hline 3 & TN:TP ratio & 0.40 & 0.83 & 1.00 & & \\
\hline 4 & Total chl a $\left(\mu \mathrm{g} \mathrm{l}^{-1}\right)$ & 0.04 & -0.02 & -0.32 & 1.00 & \\
\hline 5 & Total MC $\left(\mu g \mathrm{l}^{-1}\right)$ & $\begin{array}{c}0.15^{\mathrm{c}} \\
\left(0.15^{\mathrm{a}}, 0.43^{\mathrm{b}}\right)\end{array}$ & $\begin{array}{c}-0.56^{\mathrm{c}} \\
\left(-0.56^{\mathrm{a}}, \mathbf{- 0 . 7 9 ^ { \mathrm { b } }}\right)\end{array}$ & $\begin{array}{c}-0.61^{\mathrm{c}} \\
\left(-0.61^{\mathrm{a}},-0.41^{\mathrm{b}}\right)\end{array}$ & $\begin{array}{c}\mathbf{0 . 6 8}^{\mathrm{c}} \\
\left(\mathbf{0 . 6 8 ^ { \mathrm { a } }},-0.37^{\mathrm{b}}\right)\end{array}$ & $\begin{array}{c}1.00^{\mathrm{c}} \\
\left(1.00^{\mathrm{a}} \cdot 1.00^{\mathrm{b}}\right)\end{array}$ \\
\hline 6 & Picoplankton & 0.78 & 0.10 & 0.20 & -0.05 & $\begin{array}{c}-0.03^{\mathrm{c}} \\
\left(-0.02^{\mathrm{a}}, 0.32^{\mathrm{b}}\right)\end{array}$ \\
\hline 7 & Microcystis sp. & 0.11 & -0.30 & -0.38 & 0.73 & $\begin{array}{c}\mathbf{0 . 6 5} 5^{\mathrm{c}} \\
\left(\mathbf{0 . 6 5}{ }^{\mathrm{a}},-0.03^{\mathrm{b}}\right)\end{array}$ \\
\hline 8 & Aphanizomenon sp. & 0.28 & -0.40 & -0.25 & 0.16 & $\begin{array}{c}0.58^{\mathrm{c}} \\
\left(0.58^{\mathrm{a}}, 0.53^{\mathrm{b}}\right)\end{array}$ \\
\hline 9 & Total biovolume & 0.21 & -0.28 & -0.41 & 0.74 & $\begin{array}{c}\mathbf{0 . 7 1}^{\mathrm{c}} \\
\left(\mathbf{0 . 7 1 ^ { \mathrm { a } }},-0.01^{\mathrm{b}}\right)\end{array}$ \\
\hline \multicolumn{7}{|c|}{$\begin{array}{l}\text { bCorrelations obtained for extracellular concentration of microcystins determined by HPLC } \\
{ }^{c} \text { Correlations obtained for tal concentration of microcystins determined by HPLC }\end{array}$} \\
\hline
\end{tabular}

For the clone library of Szymoneckie (16/08/02, 2SY33), 27 clones were sequenced. Of these, 16 sequences belonged to the Anabaena/Aphanizomenon cluster (OTUs 2 and 3), 10 to the Planktothrix (OTU 5) cluster and 1 to the Limnothrix/ Pseudanabaena cluster (OTU 11) (Fig. 2).

The accumulation curve obtained for the Sulejow clone library reached an asymptote, whereas it was non-asymptotic for Szymoneckie (data not shown).

Prochlorothrix-like and pcbC gene detection. The closest relatives for the DGGE bands from samples 2TL33, 2SU35 and 2JE31 were the uncultured clones LD5, LD15 and LD7 from Lake Loosdrecht (The Netherlands) with a similarity of $99 \%$. These clones belong to the sub-cluster Prochlorothrix-like, following Zwart et al. (2005). Our sequences were also related to P. hollandica 1123 (Turner et al. 1999), but with a similarity of $92 \%$.

The detection of Prochlorothrix hollandica with specific 16S rRNA primers was tested. A positive signal was obtained for samples 2SU39, 2JE36, 2NI33, 2TL33 and 2SZ33. As P. hollandica possesses chl $b$, the environmental samples were submitted to PCR amplifications using the primer pair $p c b C-\mathrm{fw} / p c b \mathrm{C}-\mathrm{rev}$ that specifically targets the pcbC gene (Geiss et al. 2003). Though pcbC is present in the $P$. hollandica strains, it is not known whether it is also present in the subcluster 'Prochlorothrix-like', because this group is only known from its 16S rRNA sequences. A positive signal was obtained for the samples 2TL33 and 2JE36 for which DGGE sequences belonging to the Prochlorothrix-like cluster were found for the same sample (2TL33) or for another sample taken 5 wk earlier (2JE31).

\section{Correlation between the total MC concentrations and the environmental parameters}

For Sulejow, the total MC concentration slightly correlated with the total N/P $\left(\mathrm{r}_{\mathrm{s}}=-0.61\right)$, Microcystis biovolume $\left(\mathrm{r}_{\mathrm{s}}=0.65\right)$, Aphanizomenon biovolume $\left(\mathrm{r}_{\mathrm{s}}=\right.$ $0.58)$ and total biovolume $\left(\mathrm{r}_{\mathrm{s}}=0.71\right.$; Table 2$)$. No correlation with temperature was obtained $\left(\mathrm{r}_{\mathrm{s}}=0.15\right)$. The same result was obtained for the intracellular MC concentration, as the latter was the major contributor to the total MC concentration. The extracellular MC correlated with the total $\mathrm{N}\left(\mathrm{r}_{\mathrm{s}}=0.79\right)$. In the other lakes, the

Table 3. Spearman's rank correlation coefficients between biotic and abiotic parameters related to extracellular microcystin concentrations in additional lakes. Genera showing correlations lower than 0.60 are not shown. Correlations higher than 0.65 are in bold

\begin{tabular}{|c|c|c|c|c|c|c|}
\hline \multirow{2}{*}{\multicolumn{2}{|c|}{ No. Parameter (unit) }} & \multicolumn{5}{|c|}{ - Correlation } \\
\hline & & 1 & 2 & 3 & 4 & 5 \\
\hline 1 & $\mathrm{TP}\left(\mathrm{mg} \mathrm{l}^{-1}\right)$ & 1.00 & & & & \\
\hline 2 & $\mathrm{TN}\left(\mathrm{mg} \mathrm{l}^{-1}\right)$ & 0.37 & 1.00 & & & \\
\hline 3 & TN:TP ratio & 0.39 & 0.38 & 1.00 & & \\
\hline 4 & Total chl $a\left(\mu g \mathrm{l}^{-1}\right)$ & 0.21 & 0.53 & 0.52 & 1.00 & \\
\hline 5 & Extracellular MC $\left(\mu \mathrm{gl}^{-1}\right)$ & -0.55 & 0.12 & 0.30 & 0.07 & 1.00 \\
\hline 6 & Synechococcus sp. & -0.42 & 0.44 & 0.63 & 0.85 & 0.49 \\
\hline 7 & Snowella sp. & -0.51 & -0.72 & -0.17 & -0.47 & 0.43 \\
\hline 8 & Aphanocapsasp. & -0.15 & -0.16 & -0.09 & 0.35 & -0.75 \\
\hline 9 & Anabaena sp. & 0.35 & -0.24 & -0.22 & -0.26 & -0.68 \\
\hline 10 & Aphanizomenon & 0.85 & -0.02 & -0.44 & 0.21 & -0.47 \\
\hline 11 & Total biovolume & 0.64 & 0.06 & -0.25 & 0.24 & -0.89 \\
\hline
\end{tabular}


extracellular MC values negatively correlated with the Aphanocapsa biovolume $\left(\mathrm{r}_{\mathrm{s}}=-0.75\right)$, the Anabaena biovolume $\left(\mathrm{r}_{\mathrm{s}}=-0.68\right)$ and total biovolume $\left(\mathrm{r}_{\mathrm{s}}=-0.89\right.$; Table 3).

\section{DISCUSSION}

As demonstrated by Boutte et al. (2005), our results show that molecular and microscopic tools are complementary. Some discrepancies can exist between the real composition of the samples and the populations inferred from the molecular techniques. PCR may bias the detection of certain 16S rRNA sequences in mixedtemplate reactions (Ferris et al. 1997). Moreover, a partial picture of the diversity is assessed from molecular tools depending on the sequencing effort of clones and DGGE bands. Hence, on the basis of the DGGE sequences, the Microcystis population was detected in only 1 Sulejow sample out of 15 in which this genus was microscopically dominant. In contrast, microscopic tools failed to detect rare taxa: sequences from Anabaena/Aphanizomenon (Sulejow 04/06/02, 2SU23), Limnothrix/Pseudanabaena and Microcystis (Sulejow 26/06/02, 2SU26), Planktothrix (Szymoneckie 16/08/02, 2SY33) and Synechococcus (Siecino 27/08/02, 2SI35) were obtained, although these genera were not microscopically detected.

Using the same protocols for sampling and phylogenetic analyses, lakes in the Czech Republic have previously been studied (Boutte et al. 2005). Most of the Polish OTUs, including Snowella, were also detected in the Czech samples, although OTUs 3 (Anabaena/Aphanizomenon), 5 (Planktothrix), 9 (Prochlorothrix-like), 10 and 11 (Limnothrix/Pseudanabaena) were not found in Czech samples. However, these 5 OTUs were quite rare among our Polish DGGE and clone sequences.

In the Sulejow Reservoir, during the first phase (June, 2SU23 to 2SU25), no MCs were detected; this result can be linked to the low biovolumes measured $\left(<1.10^{6} \mu \mathrm{g} \mathrm{ml}^{-1}\right)$, as the total biovolume was correlated with the total MC concentration $\left(\mathrm{r}_{\mathrm{s}}=0.71\right)$.

During the second period (end of June until beginning of September; 2SU26 to 2SU36), Microcystis and Aphanizomenon were the dominant populations according to the microscopic observations (66.1 and $21.5 \%$ of the biovolume, respectively), but some small populations of Synechococcus, Snowella, Aphanocapsa and Pseudanabaena were also observed. MCs were detected from the end of July (2SU30). The highest temperature recorded $\left(26.4^{\circ} \mathrm{C}\right.$ for 2SU31) was followed by the highest MC concentration (2SU32: $6.7 \mu \mathrm{g} \mathrm{l}^{-1}$ ) measured for all samples. No correlation was found between the temperature measured and the MC concentrations, but there could be a 'long-term effect' of high temperatures. These high MC values also coincided with the decrease in the TN:TP ratio, and this ratio was moderately inversely correlated with $\mathrm{MC}$ concentrations $\left(r_{\mathrm{s}}=-0.61\right)$. Low TN:TP ratio and high temperature are thought to support the occurrence of blooms (Sivonen 1996, Kaebernick \& Neilan 2001). The MC detected could be due to the genus Microcystis (OTU 8), as it comprises the major population of toxin producers in these samples. Moreover, the Microcystis biovolume of the previous sample was much lower: $0.4 \times 10^{6} \mu \mathrm{g} \mathrm{ml}^{-1}$ for $2 \mathrm{SU} 31$ and $4.4 \times 10^{6} \mu \mathrm{g} \mathrm{ml}^{-1}$ for 2SU32. A lysis of a part of the Microcystis population can enhance the production of MCs in the surviving population (Schatz et al. 2007), and this could explain our observation. The sample 2SU35 (end of August) was quite different from the others. It included DGGE sequences belonging to the Prochlorothrix-like cluster. On this date, a low population of Pseudanabaena was detected ( $0.7 \%$ of the biovolume), and we hypothesise that this morphotype could correspond to this enigmatic cluster. In this sample, the MC concentration was also quite low $\left(1.3 \mu \mathrm{g} \mathrm{l}^{-1}\right)$.

The last period started with the sample 2SU37 in September. The MC concentration decreased very faintly from September to November (2SU37 to 2SU41). This corresponded to an increase in the TN:TP ratio (Table 1). For this period, very similar DGGE profiles from pattern (a) were recovered, and sequences related to Anabaena/Aphanizomenon (OTU 1) were obtained. The unicellular populations appeared constant, with a strong band that corresponded to Microcystis (2SU40-dggeb6). This band showed higher intensities from 2 SU37 to 2SU41, corresponding to an increase in the biovolume proportion of Microcystis (from 86.8 to $100 \%$ of the biovolume for 2SU37 and 2SU41, respectively). This was confirmed by both microscopic counts and the clone library for sample 2SU40 (02/10/02), where the 2 dominant groups of clones were related to OTUs 1 (Anabaena/Aphanizomenon) and 8 (Microcystis). Samples 2SU34 (22/08/02) and 2SU38 (19/09/02) comprised maximum Microcystis biovolumes, yet they did not have the highest total MC measurements. This might result from competitive replacement of toxic by non-toxic Microcystis strains (Kardinaal et al. 2007). Such a succession may explain the decrease in the MC concentrations measured from 22/08/02 (2SU32, $\left.6.68 \mathrm{\mu g} \mathrm{l}^{-1}\right)$ to 25/09/02 (2SU39, $1.88 \mu \mathrm{g} \mathrm{l}^{-1}$ ) for similar Microcystis biovolumes. This could also explain the moderate correlation obtained between the Microcystis biovolume $\left(\mathrm{r}_{\mathrm{s}}=0.68\right)$ and the MC concentrations.

Samples from Sulejow Reservoir showed the presence of OTU 2 in June and July followed by OTU 1 in August and September. Both OTUs belonged to the cluster Anabaena/Aphanizomenon, and this succes- 
sion of genotypes may correspond to different ecotypes. Two other OTUs belonging to the same Anabaena/Aphanizomenon lineage are found in Lakes Niegocin (2KO33) and Kotek (2NI33). The occurrence of these genotypes may be linked to specific chemical factors of the lakes, such as ionic concentrations (Willame et al. 2006).

Among the additional lakes, no correlation was found between extracellular MC measurements and TN:TP ratio. A negative correlation $\left(\mathrm{r}_{\mathrm{s}}=-0.89\right)$ was found between the MC values and the total biovolumes. Results from Sulejow Reservoir suggested that extracellular MC concentration may be negligible compared to the intracellular one. Population collapses should enhance the extracellular MC concentration after cell lysis and thus times of low biovolumes may correspond to times of the release of MC from cells. This could also explain the absence of a correlation between MC-producing genera and the extracellular $\mathrm{MC}$ concentration. The extracellular MC concentration of the sample from Lake Jeziorak (2JE36) was quite high $\left(4.1 \mu \mathrm{g} \mathrm{l}^{-1}\right)$. On the basis of the counting data, the presence of $\mathrm{MC}$ in this sample can be attributed to the small populations of Microcystis and Planktothrix.

In the Mazurian District, the highest MC value was obtained for Szymoneckie (2SY33, $4.2 \mathrm{\mu g} \mathrm{l}^{-1}$ ). This could be linked to the presence of Microcystis (counting result), of Planktothrix (according to the clone library composition) and/or to Anabaena (counting and DGGE sequences results). For the other samples, the MCs measured could be produced by the genera Anabaena, Planktothrix and Microcystis based on the affiliation of the DGGE bands and on the counting results. The highest extracellular MC values observed in this study $\left(\geq 5 \mu \mathrm{g} \mathrm{l}^{-1}\right)$ were obtained in the Pomeranian District samples from Trzesiecko (2TR35) and Siecino (2SI35). Microcystis and/or Anabaena might be the toxin producers.

Different OTUs of Anabaena/Aphanizomenon were detected in the samples showing high MC concentrations. Thus, high MC values cannot be linked to a specific OTU.

Environmental sequences similar to our clones of the Prochlorothrix-like cluster were obtained from the shallow and eutrophic Lake Loosdrecht (Zwart et al. 2005). The Polish water bodies investigated in this study are also eutrophic. We do not know if toxins are produced by the Prochlorothrix-like organisms; however, sequences related to this cluster were obtained in samples showing low (1.3 $\mu \mathrm{g} \mathrm{l}^{-1}$ in 2SU35) or moderate (3.0 $\mathrm{\mu g} \mathrm{l}^{-1}$ for 2TL33) MC values.

In 2TL33, $p c b$ C sequences were found by direct PCR detection and corresponded to the presence of DGGE sequences of the Prochlorothrix-like cluster. In other cases, the DGGE sequence was found but no $p c b C$ was detected (2SU35, 2JE31) or no DGGE sequence was obtained but the $p c b C$ signal was present (2JE36). If the Prochlorothrix-like organisms possess chl $b$ but are quite rare, the absence of signal can be due to amplification competition with more abundant sequence types in the case of the 16S rRNA, and of too low sensitivity of the PCR in the case of the $p c b C$ gene. This could also explain why only samples 2JE36 and 2TL33 were positive for the $p c b \mathrm{C}$ gene detection, whereas 5 samples had positive signals for the detection of P. hollandica based on 16S rRNA. A nested PCR for $p c b C$ detection might increase the sensitivity of this test. As the positions 800-923 around the primer 16SPholl-fw (Geiss et al. 2003) are quite specific to the Prochlorothrix-like cluster, an in situ fluorescence detection could be tested to obtain morphological data on these enigmatic organisms. Finally, we note that thin filamentous morphotypes identified as Pseudanabaena (for 2SU35, 2JE31, 2TL33) and Planktolyngbya (2JE31 and 2TL33) were microscopically detected in the samples for which the Prochlorothrix-like sequences were obtained. Thus, it is possible that these morphotypes correspond to this cluster.

\section{CONCLUSIONS}

The cyanobacterial populations from surface samples were investigated on the basis of microscopic identification, DGGE, and sequencing of clone libraries. The populations identified corresponded to dominant cyanobacterial populations commonly detected in lakes of central Europe: Microcystis, Planktothrix, Limnothrix, Anabaena or Aphanizomenon spp. (Dokulil \& Teubner 2000). Furthermore, sequences related to the Prochlorothrix-like cluster were also retrieved. This group is enigmatic and is known only from environmental clone sequences of a Dutch lake (Zwart et al. 2005) but might correspond to thin oscillatorial morphotypes. The genera Anabaena and Microcystis were probably the main toxin producers at the surface of the Polish lakes investigated. We also observed a succession of 2 different OTUs inside the Anabaena/Aphanizomenon lineages in the Sulejow Reservoir.

The TP and TN in almost all investigated Polish water bodies exceeded the limit values for eutrophication of reservoirs (0.1 $\mathrm{mg} \mathrm{P} \mathrm{l}^{-1}$ and $1.5 \mathrm{mg} \mathrm{N}^{-1}$; OECD 1982). The intracellular MC measurement was statistically linked to Microcystis biovolume and to total cyanobacterial biovolume. In contrast, no relevant correlation was obtained between the extracellular MC and the physicochemical parameters or the different morphotype biovolumes. Moreover, the concentrations of chl a can be used for assessing the risks of toxicity, as chl a concentrations were correlated with the occurrence of MC. 
Acknowledgements. This work is dedicated to the memory of Dr. M. Tarczynska, who began this collaboration. It was funded by the European Union under the project MIDI-CHIP (EVK2-CT1999-00026) and the Belgian Federal Science Policy under the project B-BLOOMS (EVK2/34). We are grateful to Dr. P. von Dassow for comments and improvement of the English. The reference DGGE marker was kindly provided by P. Rajaniemi (University of Helsinki). A.W. is Associate Researcher of the National Fund for Scientific Research of Belgium (FRS-FNRS).

\section{LITERATURE CITED}

Ambrozewski Z (ed) (1980) Monitoring Zbiornika wodnego Sulejow. Wydawnictwa Komunikacji i Lacznosci, Warsaw

An JS, Carmichael WW (1994) Use of a colorimetric protein phosphatase inhibition assay and enzyme linked immunosorbent assay for study of microcystins and nodularins. Toxicon 32:1495-1507

Beltran EC, Neilan BA (2000) Geographical segregation of the neurotoxin-producing cyanobacterium Anabaena circinalis. Appl Environ Microbiol 66:4468-4474

Boutte C, Komárková J, Grubisic S, Znachor P and others (2005) A polyphasic approach to assess the cyanobacterial diversity of summer samples from Czech reservoirs. Algol Stud 117:177-195

Boutte C, Grubisic S, Balthasart P, Wilmotte A (2006) Testing of primers for the study of cyanobacterial molecular diversity by DGGE. J Microbiol Methods 65:542-550

Carmichael WW, Azevedo SM, An JS, Molica RJ and others (2001) Human fatalities from cyanobacteria: chemical and biological evidence for cyanotoxins. Environ Health Perspect 109:663-668

Chorus I, Falconer IR, Salas HJ, Bartram J (2000) Health risks caused by freshwater cyanobacteria in recreational waters. J Toxicol Environ Health B Crit Rev 3:323-347

Cole JR, Chai BTL, Farris RJ, Wang Q and others (2003) The Ribosomal Database Project (RDP-II): previewing a new autoaligner that allows regular updates and the new prokaryotic taxonomy. Nucleic Acids Res 31:442-443

de Figueiredo DR, Azeiteiro UM, Esteves SM, Goncalves FJM, Pereira MJ (2004) Microcystin-producing blooms a serious global public health issue. Ecotoxicol Environ Saf 59:151-163

> Dokulil MT, Teubner K (2000) Cyanobacterial dominance in lakes. Hydrobiologia 438:1-12

> Ferris MJ, Nold SC, Revsbech NP, Ward DM (1997) Population structure and physiological changes within a hot spring microbial mat community following disturbance. Appl Environ Microbiol 63:1367-1374

Geiss U, Bergmann I, Blank M, Schumann R, Hagemann M, Schoor A (2003) Detection of Prochlorothrix in brackish waters by specific amplification of $p c b$ genes. Appl Environ Microbiol 69:6243-6249

Giovannoni SJ, Delong EF, Schmidt TM, Pace NR (1990) Tangential flow filtration and preliminary phylogenetic analysis of marine picoplankton. Appl Environ Microbiol 56: $2572-2575$

Golterman HL, Clymo RS, Ohnstand MAM (1978) Methods for physical and chemical analysis of freshwater. IBP Hand Book No. 8. Blackwell, London

Hotto AM, Satchwell MF, Boyer GL (2007) Molecular characterization of potential microcystin-producing cyanobacteria in Lake Ontario embayments and nearshore waters. Appl Environ Microbiol 73:4570-4578

Hrouzek P, Ventura S, Lukesova A, Mugnai MA, Turrichia
S, Komarek J (2005) Diversity of soil Nostoc strains: phylogenetic and phenotypic variability. Algol Stud 117: 251-264

> Hughes JB, Hellmann JJ, Ricketts TH, Bohannan BJM (2001) Counting the uncountable: statistical approaches to estimating microbial diversity. Appl Environ Microbiol 67: 4399-4406

Janczak J (ed) (1999) Atlas of Polish lakes. Bogucki Wydawnictwo Naukowe S.C., Poznan

Jann-Para G, Schwob I, Feuillade M (2004) Occurrence of toxic Planktothrix rubescens blooms in Lake Nantua, France. Toxicon 43:279-285

Javornický P (1958) Revise některých metod pro zjišt'ování kvantity fytoplanktonu (Revision of some methods for the estimation of phytoplankton quantity). Scientific Papers of the Institute of Chemical Technology, Prague. Faculty of Technology of Fuel and Water 2:283-367

Javornický P, Komárková J (1973) The changes in several parameters of plankton primary productivity in Slapy Reservoir 1960-1967, their mutual correlations and correlations with the main ecological factors. Hydrobiol Stud 2:155-211

> Jurczak T, Tarczynska M, Karlsson K, Meriluoto J (2004) Characterization and diversity of cyanobacterial hepatotoxins (microcystins) in blooms from Polish freshwaters identified by liquid chromatography-electrospray ionisation mass spectrometry. Chromatographia 59:571-578

Jurczak T, Tarczynska M, Izydorczyk K, Mankiewicz J, Zalewski M, Meriluoto J (2005) Elimination of microcystins by water treatment processes - examples from Sulejow Reservoir, Poland. Water Res 39:2394-2406

Kaebernick M, Neilan BA (2001) Ecological and molecular investigations of cyanotoxin production. FEMS Microbiol Lett 35:1-9

Kardinaal WE, Tonk L, Janse I, Hol S, Slot P, Huisman J, Visser PM (2007) Competition for light between toxic and non-toxic strains of the harmful cyanobacterium Microcystis. Appl Environ Microbiol 73:2939-2946

Kurmayer R, Dittmann E, Fastner J, Chorus I (2002) Diversity of microcystin genes within a population of the toxic cyanobacterium Microcystis spp. in Lake Wannsee (Berlin, Germany). Microb Ecol 43:107-118

Kurmayer R, Christiansen G, Gumpenberger M, Fastner J (2005) Genetic identification of microcystin ecotypes in toxic cyanobacteria of the genus Planktothrix. Microbiology 151:1525-1533

> Lund JWG (1951) A sedimentation technique for counting algae and other organisms. Hydrobiologia 3:93-100

Mankiewicz-Boczek J, Izydorczyk K, Romanowska-Duda Z, Jurczak T, Stefaniak K, Kokociński M (2006) Detection and monitoring toxigenicity of cyanobacteria by application of molecular methods. Environ Toxicol 21:380-387

Meriluoto J, Codd GA(eds) (2005) TOXIC: Cyanobacterial monitoring and cyanotoxin analysis. Abo Akademi University Press, Turku

Nübel U, Garcia-Pichel F, Muyzer G (1997) PCR primers to amplify 16S rRNA genes from cyanobacteria. Appl Environ Microbiol 63:3327-3332

OECD (Organisation for Economic Co-operation and Development) (1982) Eutrophication of water. Monitoring assessment and control-Technical Report. OECD, Paris

Orr PT, Jones GJ (1998) Relationship between microcystin production and cell division rates in nitrogen-limited Microcystis aeruginosa cultures. Limnol Oceanogr 43: $1604-1614$

> Pilotto LS, Douglas RM, Burch MD, Cameron S and others (1997) Health effects of exposure to cyanobacteria (blue- 
green algae) during recreational water-related activities. Aust N Z J Public Health 21:562-566

Pouria S, de Andrade A, Barbosa J, Cavalcanti RL and others (1998) Fatal microcystin intoxication in haemodialysis unit in Caruaru, Brazil. Lancet 352:21-26

Rantala A, Rajaniemi-Wacklin P, Lyra C, Lepistö L, Rintal J, Mankiewicz-Boczek J, Sivonen K (2006) Detection of microcystin-producing cyanobacteria in Finnish lakes with genus-specific microcystin synthetase gene E (mcyE) PCR and associations with environmental factors. Appl Environ Microbiol 72:6101-6110

Rapala J, Sivonen K, Lyra C, Niemela SI (1997) Variation of microcystin, cyanobacterial hepatotoxins, in Anabaena spp. as a function of growth stimulation. Appl Environ Microbiol 63:2206-2212

Robertson BR, Tezuka N, Watanabe MM (2001) Phylogenetic analyses of Synechococcus strains (cyanobacteria) using sequences of $16 \mathrm{~S}$ rDNA and part of the phycocyanin operon reveal multiple evolutionary lines and reflect phycobilin content. Int J Syst Evol Microbiol 51:861-871

Saker ML, Vale M, Kramer D, Vasconcelos VM (2007) Molecular techniques for the early warning of toxic cyanobacteria blooms in freshwater lakes and rivers. Appl Microbiol Biotechnol 75:441-449

Schatz D, Keren Y, Vardi A, Sukenik A and others (2007) Towards clarification of the biological role of microcystins, a family of cyanobacterial toxins. Environ Microbiol 9: 965-970

Schloss PD, Handelsman J (2005) Introducing DOTUR, a computer program for defining operational taxonomic units and estimating species richness. Appl Environ Microbiol 71:1501-1506

Sivonen K (1996) Cyanobacterial toxins and toxin production. Phycologia 35:12-24

Editorial responsibility: William Li, Dartmouth, Nova Scotia, Canada
Stackebrandt E, Goebel BM (1994) Taxonomic note: a place for DNA-DNA reassociation and 16S rRNA sequence analysis in the present species definition in bacteriology. Int J Syst Bacteriol 44:846-849

Taton A, Grubisic S, Brambilla E, De Wit R, Wilmotte A (2003) Cyanobacterial diversity in natural and artificial microbial mats of Lake Fryxell (McMurdo Dry Valleys, Antarctica): a morphological and molecular approach. Appl Environ Microbiol 69:5157-5169

Thompson JD, Higgins DG, Gibson TJ (1994) CLUSTAL W: improving the sensitivity of progressive multiple sequence alignment through sequence weighting, position specific gap penalties and weight matrix choice. Nucleic Acids Res 22:4673-4680

Turner S, Pryer KM, Miao VP, Palmer JD (1999) Investigating deep phylogenetic relationships among cyanobacteria and plastids by small subunit rRNA sequence analysis. J Eukaryot Microbiol 46:327-338

Van de Peer Y, De Wachter R (1994) TREECON for Windows: a software package for the construction and drawing of evolutionary trees for the Microsoft Windows environment. Comput Appl Biosci 10:569-570

Ward DM, Castenholz RW (2000) Cyanobacteria in geothermal habitats. In: Whitton BA, Potts M (eds) The ecology of cyanobacteria - their diversity in time and space. Kluwer Academic Publishers, Dordrecht, p 37-59

> Willame R, Boutte C, Grubisic S, Wilmotte A, Komarek J, Hoffmann L (2006) Morphological and molecular characterisation of planktonic cyanobacteria from Belgium and Luxembourg. J Phycol 42:1312-1332

Zwart G, Kamst-van Agterveld MP, van der Werff-Staverman I, Hagen F, Hoogveld HL, Gons HJ (2005) Molecular characterization of cyanobacterial diversity in a shallow eutrophic lake. Environ Microbiol 7:365-377

Submitted: May 28, 2007; Accepted: March 3, 2008 Proofs received from author(s): May 27, 2008 